\title{
イルメナイトの選択塩素化に及ぼす各種因子 の影響についで
}

\author{
木 村 悦 治 ${ }^{1}$ 不 破 章 雄 ${ }^{2}$ \\ 福 島 清 太 郎 ${ }^{3}$
}

1. 緒

言

イルメナイトを塩素化するプロセスは, 鉄とチタンの両 方を塩素化する場合と鉄だけを選択的に塩素化する場合の 2 つに大別できる。前者は四塩化チタン又は顔料 $\mathrm{TiO}_{2}$ を 目的としており，後者は人工ルチル製造のためのプロセス である。イルメナイトから選択的に鉄を塩素化して人工ル チルを製造する方法は古くから提案されているが, ${ }^{1) ~}$ 塩 素の回収,リサイクルを含めた一貫プロセスとして完成し ているプロセスは少なく，塩素化反応や脱塩素化反応につ いてもモデル化して定量的な考察を加えた例は皆無である。

三菱金属では 1971 年以来, 塩素法による人工ルチル 製造プロセスの開発をおこない,このプロセスの概要は

1974年A IME Annual Meeting で発表した。 口セスは鉱石の酸化焙焼工程, 塩素化工程, 選鉱工程, 脱 塩素化工程, ガス精製工程, 塩素の液化回収工程の 6 工程 からなる。このうち塩素化工程, 脱塩素化工程, 塩素の液 化回収工程についてはすでに詳細に報告した。 素化工程ではコークスの共存下で流動炬により塩素化する が, 塩素化のための諸因子 一 温度, 塩素分圧, コークス 添加率，鉱石の粒度一の影響を明らかにした。

本報告ではイルメナイトの塩素化の際の鉄とチタンの選 択塩素化に影響する因子および鉄以外の不純物（ $\mathrm{SiO}_{2}$ ， $\mathrm{Al}_{2} \mathrm{O}_{3}, \mathrm{CaO}, \mathrm{MgO}, \mathrm{MnO}$ ○ど)の挙動をとりあつかつて いる。さらに前回の報告ではオーストラリア産イルメナイ 卜を使つて, 塩素化反応が unreacted shrinking core mode $1^{15)}$ で説明できることを示したが, 種類の異なる他の イルメナイト鉱石についても成り立つかどうかを調べた。

\section{2. 実 験 方 法}

\section{$2 \cdot 1$ 試料}

実験に使用したオーストラリア産イルメナイトの組成お よび粒度分布を Table 1に示した。イルメナイト鉱石は実 験に先だち $950^{\circ} \mathrm{C}$ 空気中で $\mathrm{Fe}^{2+}$ が $1 \%$ 以下になるまで焙 焼した。これは塩素化したとき $\mathrm{Fe}^{2+}$ のため $\mathrm{FeCl}_{2}(l)$ が 生成し流動性をさまたげたり, 塩素化炉出口煙道の閉塞の 原因になるためである。焙焼により粒度分布はほとんど変 化しなかつたが，比表面積は $5.19 \mathrm{~m}^{2} / \mathrm{g}$ から $0.145 \mathrm{~m}^{2} / \mathrm{g}$

* 1978年9月 7 日受理

1. 正会員 株式会社三菱金属中央研究所研究員

2. 三菱金属株式会社総務部 $(=ュ-\exists ー ク$ 駐在 $)$

3. 室蘭工業大学教授 工学研究科エネルギー工学専攻
Table 1 Australian ilmenite

\begin{tabular}{lccr}
\hline \multicolumn{2}{c}{ Chemical analyses } & \multicolumn{2}{c}{ Size distribution } \\
\hline $\mathrm{TiO}_{2}$ & $53.40 \mathrm{wt} \%$ & mesh & wt $\%$ \\
$\mathrm{FeO}$ & 20.16 & -48 & 0.6 \\
$\mathrm{Fe}_{2} \mathrm{O}_{3}$ & 19.67 & $48-65$ & 9.2 \\
$\mathrm{Al}_{2} \mathrm{O}_{3}$ & 1.70 & $65-80$ & 18.2 \\
$\mathrm{SiO}_{2}$ & 1.36 & $80-100$ & 16.5 \\
$\mathrm{MnO}$ & 1.68 & $100-120$ & 40.9 \\
$\mathrm{~V}_{2} \mathrm{O}_{5}$ & 0.11 & $120-150$ & 6.4 \\
$\mathrm{MgO}$ & 0.25 & $150-170$ & 7.7 \\
Specific surface area & $170-$ & 0.5 \\
True density & $5.19 \mathrm{~m}^{2} / \mathrm{g}$ & \\
\hline
\end{tabular}

Table 2 Petroleum coke

\begin{tabular}{lccr}
\hline \multicolumn{2}{c}{ Chemical analyses $(\mathrm{wt} \%)$} & \multicolumn{2}{c}{ Size distribution } \\
\hline $\mathrm{H}_{2} \mathrm{O}$ & 0.04 & mesh & wt $\%$ \\
Ash & 0.52 & $20-42$ & 63.8 \\
V.M. & 0.81 & $42-60$ & 14.2 \\
F.C. & 98.67 & $60-80$ & 10.5 \\
& & $80-100$ & 5.3 \\
& & $100-150$ & 4.4 \\
& & $150-$ & 1.8 \\
\hline
\end{tabular}

V.M.; Volatile material F.C.; Fixed carbon

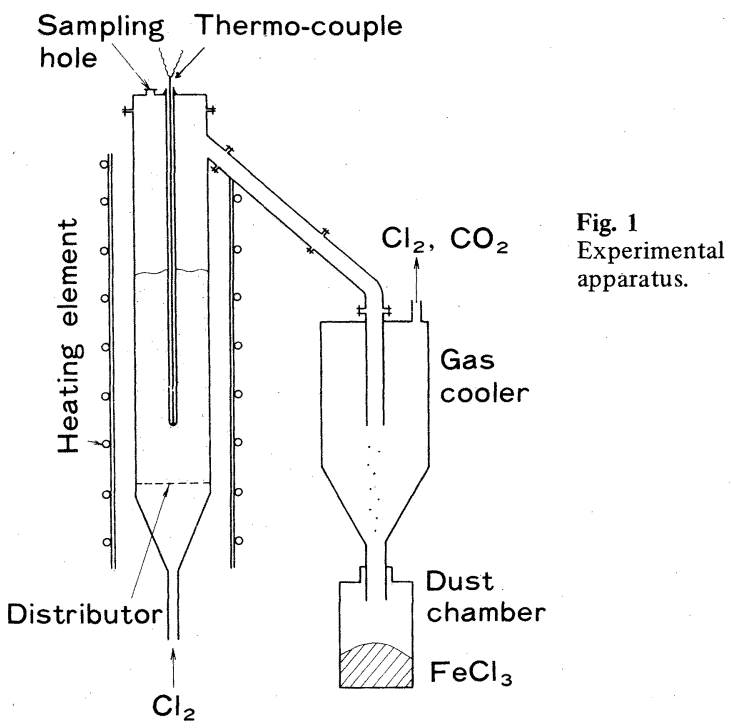

まで大幅に減少した。これは鉱石の表面にでている細孔が 焙焼により減少したことを示している。さらに鉱石の平均 粒度は 100〜120 meshにあり流動性も良かつた。還元剤 としては石油焼成コークスを使用したが，これは水分，揮 
発分ともに少なく，固定炭素が多く流動性も良かつた。こ のコークスの組成抢よび粒度分布はTable 2 に示した。

\section{$2 \cdot 2$ 装置および方法}

イルメナイトの塩素化に使用した装置をFig. 1に示した。 反応管は透明石英製, 径 $4.5 \mathrm{~cm}$, 長さ $60 \mathrm{~cm}$ で分散板は 透明石英板に径 $1 \mathrm{~mm}$ の穴をあけたものを使用した。反応 管を常温でカンタル抵抗炉内にセットし, 実駼温度 880 $960^{\circ} \mathrm{C}$ まて昇温した。昇温後, 鉱石とコークスを所定の割 合に混合した試料を反応管内に $\mathrm{N}_{2}$ ガスを流しながら装入し た。装入時に炉内温度は下降するが,そのまま $\mathrm{N}_{2}$ ガスで流動 を維持し,設定温度まで回復した後 $\mathrm{N}_{2}$ ガスを $\mathrm{Cl}_{2}$ ガスに切り替 えた。反応温度は流動層内で測定し, 反応速度の指針ため の試料は一定時間毎に流動層内から採取された。一回のサ ンプリング量は約 $5 \mathrm{~g}$ で試料中のコークスを燃焼した後,Feお了 よび $\mathrm{TiO}_{2}$ 品位を分析した。 $\mathrm{Cl}_{2}$ ガスは炬内で $\mathrm{Fe}_{2} \mathrm{O}_{3}, \mathrm{TiO}_{2}$, その他の不純物と反応し, 生成した塩化鉄やその他の塩化 物は流動層を出た後ダストチャンバで捕集された。このダ ストチャソバから出たガス中の $\mathrm{Cl}_{2}, \mathrm{CO}_{2}$ 分圧はガスクロマ トグラフィーにより分析した。

以上イルメナイトからの脱鉄速度を調べるための実験方 法について述べたが，鉄とチタンの選択性を定量的に評価 する場合は, 実験毎に一定時間経過後, $\mathrm{Cl}_{2}$ をとめ残留鉱 石量を測定した。残留鉱石中の $\mathrm{Fe}$ と $\mathrm{TiO}_{2}$ の分析值から反 応した $\mathrm{Fe}$ 量の割合と反応した $\mathrm{TiO}_{2}$ 量の割合を求めた。さ らに流動炉以外に横型炉によるボート試験を実施した。粒 度の異なる 3 種類のイルメナイトをそれぞれ磁性ボートに 入れ，ガスの流れに平行にならべて同時に塩素化した。反 応後その重量減少と $\mathrm{Fe}, \mathrm{TiO}_{2}$ 品位から $\mathrm{Fe}$ と $\mathrm{TiO}_{2}$ の反応 量を計算した。

\section{3. 実験結果と考察}

\section{$3 \cdot 1$ イルメナイトの塩素化反応}

$3 \cdot 1 \cdot 1$ 塩素化反応速度 イルメナイトの塩素化速 度についてはすでに 1977 年AIME Annual Meetingで 発表されたが，鉄の塩素化は反応の進行とともに粒子の外 殸に $\mathrm{TiO}_{2}$ を残して,中心に向つて反応が進行していく unreacted shrinking core modelで, しかも化学反応 律速であることが示された。 これを式で表現すると(1) (5) 式に整理できる。

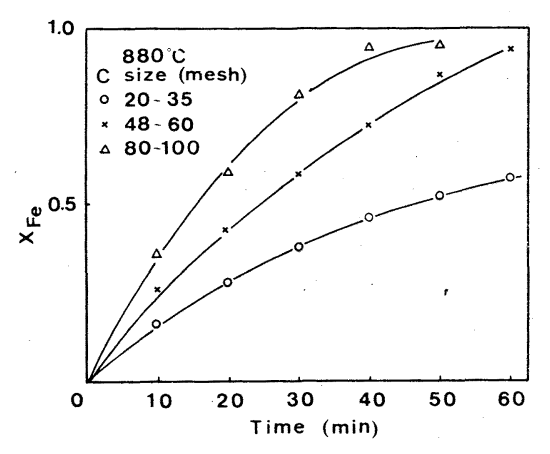

Fig. 2 Chlorination rate at various coke sizes.

$$
\begin{aligned}
& 1-\left(1-X_{\mathrm{Fe}}\right)^{1 / 3}=t / \tau_{\mathrm{Fe}_{2} \mathrm{O}_{3}} \\
& \tau_{\mathrm{Fe}_{2} \mathrm{O}_{3}}=\rho_{\mathrm{Fe}_{2} \mathrm{O}_{3}} d_{p \text {.ore }}^{\circ} / 2 b K_{c\left(\mathrm{Fe}_{2} \mathrm{O}_{3}\right)} C_{\mathrm{OO}_{2}} \cdots \cdots \cdots \cdots \text { (2) } \\
& k_{c}\left(\mathrm{Fe}_{2} \mathrm{O}_{3}\right)=2.0 \times 10^{4} \exp (-39000 / \mathrm{RT}) R_{c o}{ }^{1.8} R_{c . j}^{0.38} \\
& R_{c o}=0.089 \text { (coke/ore) } \\
& \text { …................ (3) } \\
& R_{c . j}=0.089 \text { (coke/ore) }\left(1-X_{\text {coke }}\right)^{2 / 3} /\left(1-X_{\mathrm{Fe}}\right)^{2 / 3}
\end{aligned}
$$

さらに実験範囲での塩素化条件の下ではの○はほとんど検 出されず，大部分が $\mathrm{CO}_{2}$ であることが確認されていること から,

$X_{\text {coke }}=0.048\left(\right.$ ore $/$ coke) $X_{\mathrm{Fe}}$

で表わされる。

ここで,

$t:$ 反応時間 $(\min )$

$\tau$ : 反応完結時間 ( min)

$b$ : $1 / 3$ (塩素 1 モルと反応する $\mathrm{Fe}_{2} \mathrm{O}_{3}$ のモル数)

$C_{\mathrm{Cl}_{2}}$. 塩素濃度 $\left(\mathrm{g}-\mathrm{mole} / \mathrm{cm}^{3}\right)$

$R$ ： ガス定数 ( cal/deg. mole )

( coke /ore):ユークスと鉱石の最初の混合比

$X_{\text {coke }}$ ：最初のコークス量に対する反応コークス量の 割合

$X_{\mathrm{Fe}}$ ：最初の鉱石量に対する反応鉱石量の割合 $($ - )

$\rho_{\mathrm{Fe}_{2} \mathrm{O}_{3}}: \mathrm{Fe}_{2} \mathrm{O}_{3}$ の密度 $\left(\mathrm{g}-\mathrm{mole} / \mathrm{cm}^{3}\right)$

$d_{p \cdot o r e}^{\circ}$ ：反応前の鉱石の粒子径 $(\mathrm{cm})$

である。

$3 \cdot 1 \cdot 2$ コークス粒度の影響 $3 \cdot 1 \cdot 1$ における反 応速度式は平均粒径 450 ミクロンのコークスを混合比をか えて導いたが，ここでは使用したコークスの粒度の影響を 分離するために、コークスの粒度を変えて実験した。この 結果をFig.2に示したが, 塩素化反応速度はコークスの粒 度が細かいほど大きかつた。これは定性的にはコークスの 粒度が細かいほど, 同じ混合比では鉱石とコークスの接触 率が大きく還元雾囲気が強くなることから反応速度が大き くなると考えられる。Fig.2の結果を $1-\left(1-X_{\mathrm{Fe}}\right)^{1 / 3}$ と $t$ の関係で整理すると Fig. 3が得られた。この直線の傾きは $\left(1 / \tau_{\mathrm{Fe}_{2} \mathrm{O}_{3}}\right)$ で, $d c$ の依存性を Fig.4に示した。(2)式で $\rho_{\mathrm{Fe}_{2} \mathrm{O}_{3}}, d_{p}^{\circ}$. ore $, b, C_{\mathrm{Cl}_{2}}$ はコークス粒度 $\left(d_{c}\right)$ が変化して も一定であるため $\tau_{\mathrm{Fe}_{2} \mathrm{O}_{3}}$ と $d_{c}$ の依存性加ら $k_{c}\left(\mathrm{Fe}_{2} \mathrm{O}_{3}\right)$ と $d_{c}$ の 依存性が得られる。すなわち(3), (4)式から(7)式を得, これ

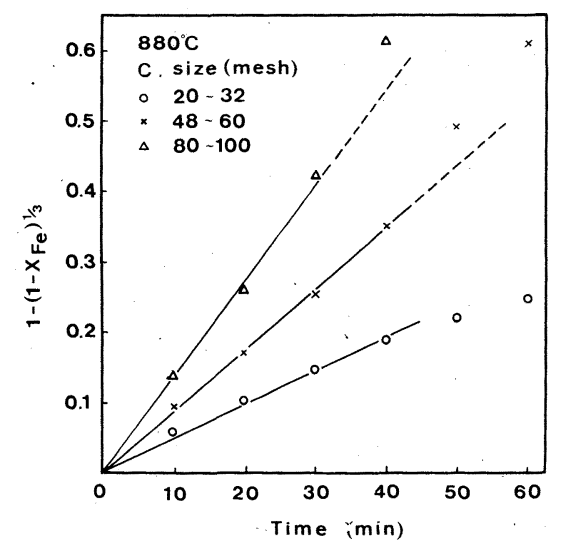

Fig. 4
$\begin{aligned} & \text { Completion time } \\ & \text { vs. coke } \\ & \text { diameter }\left(d_{c}\right) .\end{aligned}$
$\therefore$
$\leftarrow$ Fig. 3
$1-\left(1-\mathrm{X}_{\mathrm{Fe}}\right)$
$1 / 3$ 


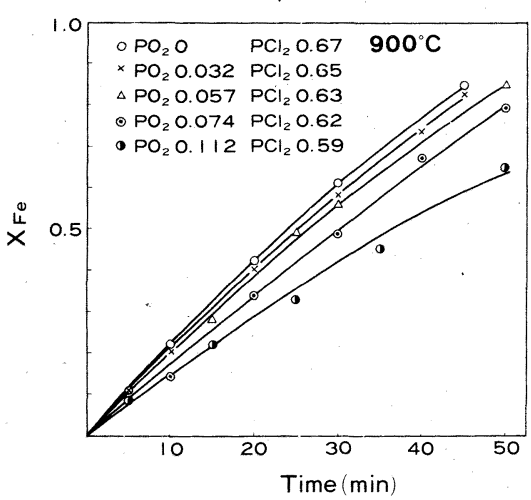

Fig. 5 Effect of oxygen partial pressure on the chlorination rate.

Table 3 Analyses of cokes

\begin{tabular}{lrrrl}
\hline & $\mathrm{H}_{2} \mathrm{O}$ & \multicolumn{1}{c}{ Ash } & \multicolumn{1}{c}{ V.M. } & F.C. \\
\hline Petroleum coke (A) & 0.23 & 1.59 & 1.15 & 97.26 \\
Petroleum coke (B) & 0.15 & 0.54 & 0.94 & 98.52 \\
Petroleum coke (C) & 1.06 & 0.80 & 10.00 & 89.20 \\
Coal coke & 0.75 & 10.38 & 1.27 & 88.35 \\
Graphite & 0.10 & 1.27 & 0.69 & 98.04 \\
Charcoal & 6.24 & 1.38 & 7.76 & 90.86 \\
Anthracite & 1.92 & 3.13 & 6.73 & 88.22 \\
\hline
\end{tabular}

V.M.; Volatile material F.C.; Fixed carbon A; Coarse

B; Fine C; Uncalcined Fraction; wt $\%$

Table 4 Size distribution of cokes

\begin{tabular}{lrrrrrr}
\hline & $20-42$ & $42-60$ & $60-80$ & $80-100$ & $100-150$ & $150-$ \\
\hline Petroleum coke (A) & 31.1 & 20.4 & 17.2 & 10.3 & 11.8 & 9.2 \\
Petroleum coke (B) & 66.7 & 11.4 & 6.8 & 3.9 & 4.5 & 6.7 \\
Petroleum coke (C) & 48.1 & 13.8 & 9.1 & 6.1 & 9.0 & 13.9 \\
Coal coke & 30.7 & 11.7 & 11.0 & 8.7 & 10.9 & 27.0 \\
Anthracite & 53.6 & 16.3 & 10.2 & 5.4 & 6.2 & 8.3 \\
Graphite & 59.4 & 7.3 & 5.3 & 4.3 & 6.6 & 17.2 \\
Charcoal & 40.8 & 9.4 & 6.5 & 7.1 & 7.9 & 28.3 \\
\hline
\end{tabular}

A; Calcined (Fine) B; Calcined (Coarse) C; Uncalcined Size; mesh Fraction; wt $\%$

に $d_{c}$ 依存性を入れて(8)式になつた。

$k_{c}\left(\mathrm{Fe}_{2} \mathrm{O}_{\mathrm{s}}\right)=2.59 \times 10^{2} \exp (-39000 / \mathrm{RT})(\mathrm{coke} / \mathrm{ore})^{18} R_{c} \cdot j^{0.38}$

$k_{c}\left(\mathrm{Fe}_{2} \mathrm{O}_{3}\right)=2.53 \exp (-39000 / \mathrm{RT}) d_{c}{ }^{-0.75}(\text { coke/ore })^{18} R_{c . j}^{0.88}$

$3 \cdot 1 \cdot 3$ 酸素分圧の影響 イルメナイトの塩素化反 応はコークスの存在下で塩素と反応させるため, 反応機構 にもよるが，反応途中で生成した $\mathrm{O}_{2}$ または $\mathrm{CO}, \mathrm{CO}_{2}$ によ り形成される酸素分圧しかもたない。このため反応速度式 のなかに酸素分圧の項を入れる必要はないが，実用的には 反応炉の温度コントロールのため酸素を導入する場合があ る。そこで反応速度に及ぼす酸素分圧の影響を明らかにし ておく必要がある。 $900^{\circ} \mathrm{C}, p_{\mathrm{O}_{2}}=0 \sim 0.112 \mathrm{~atm}$. coke /ore $=0.15$ で塩素化実験をおこなつた。その結果をFig. 5 に示した。酸素分圧が高くなると還元雾囲気が弱くなり 反応速度が遅くなることは当然予想されるがFig. 5 の結果 を $1-\left(1-X_{\mathrm{Fe}}\right)^{1 / 3}$ と $t$ の関係に整理して $(1)$ 式から $\tau_{\mathrm{Fe}_{2} \mathrm{O}_{\mathrm{s}}}$ をを 求め, これをコークス添加量をかえたときの $\tau_{\mathrm{Fe}_{2} \mathrm{O}_{3}}$ と比較

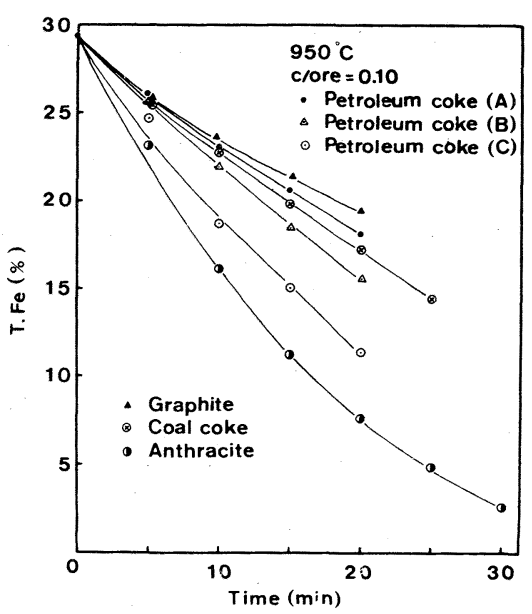

Fig. 7 Chlorination rate by various reducing agents. A; Calcined (coarse) B; Calcined (fine) C; Uncalcined

することで, 酸素分圧と ( coke/ore ) との対応関係を得 た。これをFig. 6 に示した。これからたとえは酸素を $p_{\mathrm{O}_{2}}$ $=0.05 \sim 0,1 \mathrm{~atm} \mathrm{Cl}_{2}$ とともに導入したとき，実際には ( coke/ore) が 0.15 であつても反応速度上は（coke) or e ）が $0.12 ， 0.09$ の場合にあたることがわかつた。

$3 \cdot 1 \cdot 4$ コークスの種類による影響 $3 \cdot 1 \cdot 1$ では コークスとして石油燒成コークスを使用したが，ここでは それ以外のコークスについて反応性の差を調べた。使用し たコークスの種類と組成を Table 3 に粒度分布を Table 4 に示した。これらから特に未焼成石油コークスは揮発分が 多く，木炭は灰分が多いことがかかる。また粒度分布は二 ークスの種類によらず 20〜 42 mesh に集まつているが, 木炭, 無煙炭は 150 mesh 以下も $27 \sim 28 \%$ 存在寸る。こ れらのコークスを使つて $950^{\circ} \mathrm{C}$, coke/ore $=0.1, \mathrm{Cl}_{2}$ $=3 \mathrm{l} / \mathrm{min}$ の条件で塩素化した結果をFig.7に示した。使 用したコークスを反応性の良い順にならべると，無煙炭， 石油未焼成コークス, 石油焼成コークス（細口）, 石炭コ 一クス, 石油焼成コークス (粗口), 黒鉛となつた。木炭 は反応開始とともに煙道の閉塞が激しく十分なデータが得 られなかつた。コークスの反応速度に及ぼす影響のうち， 鉱石との混合比, 粒子径については定量的に評価されてい るが, それ以外の要因, 特に比表面樍, 表面の反応に対す る活性度については定量的に評価されていない。このため, 本実験のように一定の混合比で粒子径も顕著な差がないと きはその反応速度の差を定量的に説明することはむずかし い。ただし石油焼成コークスのように同じ種類で粒子径が ちがう場合は粒子径の小さいほど反応速度が速いことは(8) 式で説明できる。またコークスの選択にあたつては反応性 ばかりでなく, 化学成分も考慮しなければならない。無煙 炭, 石油未焼成コークスなどは反応性は良いが, 灰分や揮 発分が多く, 人工ルチルの品質低下や塩素口スなどの原因 になるため好ましくない。さらに木炭は水分, 石炭コーク スは灰分が多く，黒鉛は粒度調整，反応性の面で問題があ るため使用するコークスとしては反応性と化学成分から石 油焼成コークス (細口) が好ましい。 

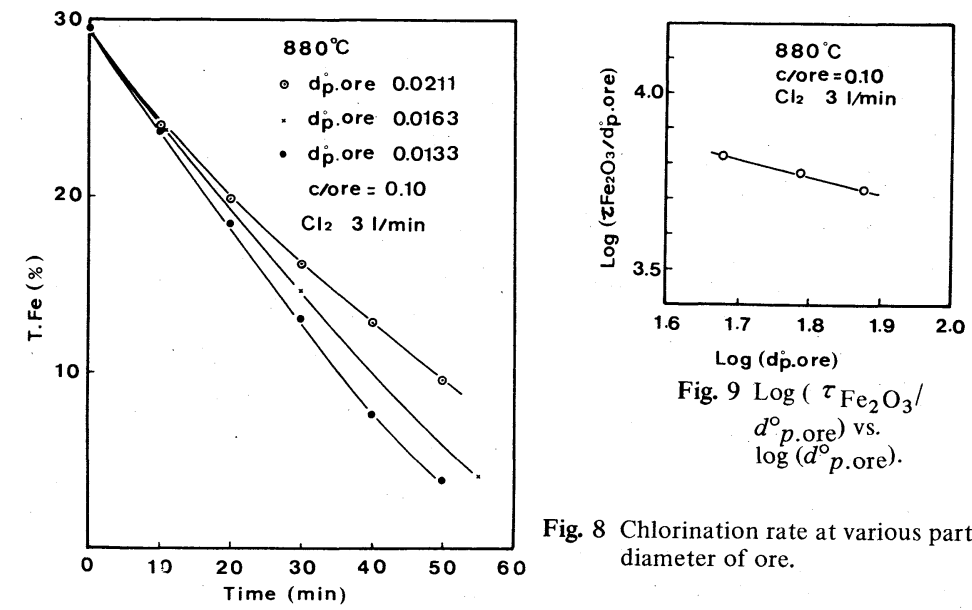

Fig. $9 \mathrm{Log}\left(\tau_{\mathrm{Fe}_{2} \mathrm{O}_{3}} /\right.$ $d^{\circ} p$.ore $)$ vs.

Fig. 8 Chlorination rate at various particle diameter of ore.

\section{$3 \cdot 1 \cdot 5$ 鉱石の粒度の影響 鉱石の粒度が変化する} と(2)式のunreacted shrinking core modelの式から予想 されるように粒度に反比例するだけでなく, 鉱石とコークス の相対的な流動層内での分布の差, 流動性の変化などによる 影響がある。これを平均粒径 $211 \mu, 163 \mu, 133 \mu$ 鉱石に ついて調べFig. 8に示した。これを(1)式にしたがつて整理 $し て, \tau_{\mathrm{Fe}_{2} \mathrm{O}_{3}} / d_{p \text {. ore }}^{\circ} d_{p \text {.ore }}^{\circ}$ の関係を求めFig.9を得た。 この直線の傾きは $1 / k_{c}\left(\mathrm{Fe}_{2} \mathrm{O}_{3}\right)$ の粒度依存性を示しており $k_{c}\left(\mathrm{Fe}_{2} \mathrm{O}_{3}\right)$ は(9)式であらわされる。

$$
\begin{aligned}
k_{c}\left(\mathrm{Fe}_{2} \mathrm{O}_{3}\right)= & 1.87 \times 10^{2} \exp (-39000 / \mathrm{RT}) d_{p \text { ore }}^{0.475} d_{c}{ }^{-0.75} \\
& (\text { coke/ore })^{18} R_{c \cdot j}{ }^{0.38} \ldots \ldots \ldots \ldots \ldots \ldots \ldots(9)
\end{aligned}
$$

\section{$3 \cdot 2$ 選択性に及ぼす各種因子の影響について}

$3 \cdot 2 \cdot 1$ 選択性に寄与する因子 イルメナイトから 鉄分だけを塩素化して $\mathrm{TiO}_{2}$ を濃縮する場合，鉄と同時に $\mathrm{TiO}_{2}$ も塩素化するのでこれをできるだけ抑えるため, 鉄 を選択的に除去する条件を確立しておく必要がある。鉄の 塩素化速度は(1)式で表されるがチタンについても同じよう に(10)式で表わされる。

$$
1-\left(1-X_{\mathrm{TiO}_{2}}\right)^{1 / 3}=t / \tau_{\mathrm{TiO}_{2}}
$$

(1)式と(10)式で同じ反応時間が経過したときの $\mathrm{Fe}_{2} \mathrm{O}_{3}$ と $\mathrm{TiO}_{2}$ の塩素化率の関係は(11)式で表わされる。

$$
\begin{array}{r}
{\left[1-\left(1-X_{\mathrm{TiO}_{2}}\right)^{1 / 3}\right] /\left[1-\left(1-X_{\mathrm{Fe}}\right)^{1 / 3}\right]=\tau_{\mathrm{Fe}_{2} \mathrm{O}_{3}} / \tau_{\mathrm{TiO}_{2}}} \\
\ldots \ldots \ldots \ldots \ldots \ldots \ldots \ldots \text { (11) }
\end{array}
$$

ここで $\mathrm{TiO}_{2}$ の塩素化率が 1 にくらべてかなり小さいと きは(12)式が成り立つ。

$$
\left(1-X_{\mathrm{TiO}_{2}}\right)^{1 / 3} \fallingdotseq 1-1 / 3 X_{\mathrm{TiO}_{2}}
$$

(12)式を(11)式に代入して(13)式を得た。

$$
X_{\mathrm{TiO}_{2}}=\left(3 \tau_{\mathrm{Fe}_{2} \mathrm{O}_{3}} / \tau_{\mathrm{TiO}_{2}}\right)\left[1-\left(1-X_{\mathrm{Fe}}\right)^{1 / 3}\right.
$$

$\tau_{\mathrm{Fe}_{2} \mathrm{O}_{3}}$ については(2)式が適用でき $\tau_{\mathrm{Ti}_{2}}$ は(14)式で与えら れる。

$$
\tau_{\mathrm{TiO}_{2}}=\rho_{\mathrm{TiO}_{2}} \cdot d_{p \cdot \text { ore }}^{\circ} / 2\left(\frac{1}{2}\right) k_{c}\left(\mathrm{TiO}_{2}\right) C_{\mathrm{Cl}_{2}}^{n}
$$

八木 ${ }^{16)} \mathrm{A}$. Bergholm ${ }^{17)}$ によれば反応速度は塩素分圧に 比例することから $n=1.0$ とし $\rho_{\mathrm{Fe}_{2} \mathrm{O}_{3}}=2.303 \times 10^{-2} \mathrm{~g}$-mole $/ \mathrm{cm}^{3}, \rho_{\mathrm{TiO}_{2}}=2.856 \times 10^{-2} \mathrm{~g}-\mathrm{mole} / \mathrm{cm}^{3}$ を(2), (14式に代 入すると(15)式を得る。

$$
\tau_{\mathrm{Fe}_{2} \mathrm{O}_{3}} / \tau_{\mathrm{TiO}_{2}}=1.21\left(k_{c}\left(\mathrm{TiO}_{2}\right) / k_{c}\left(\mathrm{Fe}_{2} \mathrm{O}_{3}\right)\right) \quad \cdots \cdots(15)
$$

以上から $X_{\mathrm{TiO}_{2}}$ は(11)式の $\tau_{\mathrm{Fe}_{2} \mathrm{O}_{3}} / \tau_{\mathrm{TiO}_{2}}$ の值すなわち $k_{c}\left(\mathrm{TiO}_{2}\right)$
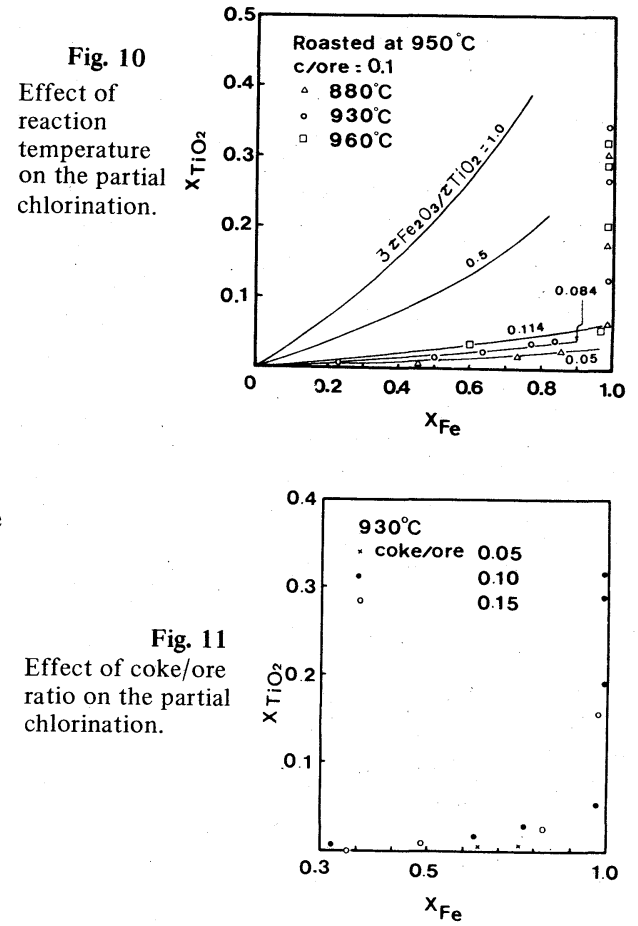

$/ k_{c}\left(\mathrm{Fe}_{2} \mathrm{O}_{3}\right)$ の值に依存する。そしてこの $k_{c}\left(\mathrm{TiO}_{2}\right), k_{c}\left(\mathrm{Fe}_{2} \mathrm{O}_{3}\right)$ は次の 4 因子によつて影響される。
(a) 反応温度
(b) 焙焼温度
(c) 還元雾囲気の強さ (coke/ore 比)
(d) 鉣石の粒度

ここで特に焙焼温度は $\mathrm{Ti} \mathrm{O}_{2}$ と共存する相変化の原因と なり(9)式の定数項 $1.87 \times 10^{2}$ の值に影響する。 ${ }^{11) 18)}$

次に個々の因子について詳述した。

\section{$3 \cdot 2 \cdot 2$ 反忘温度 $\quad 950^{\circ} \mathrm{C}$ て酸化焙焼した鉱石を} $880 \sim 960^{\circ} \mathrm{C}$ で塩素化し， $X_{\mathrm{Fe}}$ と $X_{\mathrm{TiO}_{2}}$ の関係を調べた。 の結果を Fig.10に示したが， $X_{\mathrm{Fe}} \leqq 0.8 て ゙ は X_{\mathrm{TiO}_{2}}$ は 0.04 以下で(12)式は十分に成立し，(13)（15)式が適用できる。この 図から $880^{\circ} \mathrm{C}, 930^{\circ} \mathrm{C}, 960^{\circ} \mathrm{C}$ での $\tau_{\mathrm{Fe}_{2} \mathrm{O}_{3}} / \tau_{\mathrm{TiO}_{2}}$ の值が求め られた。

$$
\begin{aligned}
& \tau_{\mathrm{Fe}_{2} \mathrm{O}_{3}} / \tau_{\mathrm{TiO}_{2}}=0.017 \quad\left(880^{\circ} \mathrm{C}\right) \quad \cdots \cdots \cdots \cdots(16) \\
& \tau_{\mathrm{Fe}_{2} \mathrm{O}_{3}} / \tau_{\mathrm{TiO}_{2}}=0.028 \quad\left(930^{\circ} \mathrm{C}\right) \cdots \cdots \cdots \cdots(17) \\
& \tau_{\mathrm{Fe}_{2} \mathrm{O}_{3}} / \tau_{\mathrm{TiO}_{2}}=0.038 \quad\left(960^{\circ} \mathrm{C}\right) \quad \cdots \cdots \cdots \cdots \text { (18) }
\end{aligned}
$$

(16), (17), (18)式と $\ln \left(\tau_{\mathrm{Fe}_{2} \mathrm{O}_{3}} / \tau_{\mathrm{TiO}_{2}}\right)$ vs. $1 / T$ の関係加ら(19) 式を得た。

$$
3 \tau_{\mathrm{Fe}_{2} \mathrm{O}_{3}} / \tau_{\mathrm{TiO}_{2}}=3.6 \times 10^{-7} \exp (29200 / \mathrm{RT}) \cdots(19)
$$
これを(13)式に代入して鉄とチタンの選択性を示す20式を得 た。

$$
\begin{array}{r}
X_{\mathrm{TiO}_{2}}=3.6 \times 10^{-7} \exp (29200 / \mathrm{RT})\left[1-\left(1-X_{\mathrm{Fe}}\right)^{1 / 3}\right] \\
(\text { coke } / \text { ore }=0.1) \cdots(20)
\end{array}
$$

$3 \cdot 2 \cdot 3$ コークス添加率 選択性に及ぼすコークス 添加率の影響を Fig. 11に示した。これは $930^{\circ} \mathrm{C}$, coke/ ore $=0.05,0.1,0.15, \mathrm{Cl}_{2}$ 流量 $=3 \mathrm{l} / \mathrm{min}$ で実施した。 この図から 0.05，0.1では差がはつきりと出ているが， 0.1 と 0.15 の差はほとんどでていない。このため coke/ore $=0.05$ と 0.1 では $\tau_{\mathrm{Fe}_{2} \mathrm{O}_{3}} / \tau_{\mathrm{TiO}_{2}}$ の值は求まるが coke/ore 
$=0.15$ では信頼性が薄い。coke/ore $=0.1$ の場合は $\tau_{\mathrm{Fe}_{2} \mathrm{O}_{3}} / \tau_{\mathrm{TiO}_{2}}$ の值は(17)式で求められており, 0.05 の場合を (21)式で示した。

$$
\tau_{\mathrm{Fe}_{2} \mathrm{O}_{3}} / \tau_{\mathrm{TiO}_{2}}=0.015
$$

(17), (21)式から coke/ore $=0.05 \sim 0.1$ では(22)式が成立す る。

$$
\begin{aligned}
X_{\mathrm{TiO}_{2}} & =2.86 \times 10^{-6}(\text { coke/ore })^{0.9} \exp (29200 / \mathrm{RT}) \\
& \times\left[1-\left(1-X_{\mathrm{Fe}}\right)^{1 / 3}\right] \quad \ldots \ldots \ldots \ldots \ldots \ldots \ldots \ldots \ldots \ldots \ldots \ldots \ldots \ldots \ldots \ldots \ldots
\end{aligned}
$$

$3 \cdot 2 \cdot 4$ 鉱石の粒度 鉱石の粒度は unreacted shrinking core model からだけでは反応速度の絶対値 には影響するが，鉱石中のTi と Feが均一に分布している かぎり $\mathrm{TiO}_{2}$ と $\mathrm{Fe}$ の選択性には影響しない。すなわち粒度 が小さくなると脱鉄速度も大きくなるが $\mathrm{TiO}_{2}$ の塩素化速 度も大きくなる。そこでこれを確認するために, 横型炬内 で 48〜80 mesh , 80〜100 mesh, 100〜150 meshの 鉱石とコークスの混合試料をそれぞれボートに入れ, 同じ 均熱温度部分で同時に塩素化した。この結果をFig. 12 に 示したが, 鉣石の粒度によつて選択性に差がみられなかつ た。

しかし流動炉による実験ではFig. 13 にみられるように 鈗石の粒度が粗いほど選択性は悪かつた。この原因は鉱石 の粒度による流動性の差や鈗石に対する相対的なコークス の分布率などが変化して $(9)$ 式のごとく $k_{c}\left(\mathrm{Fe}_{2} \mathrm{O}_{3}\right)$ が変化す るためと考えられる。

$3 \cdot 2 \cdot 5$ 焙焼温度 イルメナイトの塩素化する際, $\mathrm{Fe}^{2+}$ は $\mathrm{FeCl}_{2}(l)$ を生成して流動をさまたげる原因になるので 空気で酸化焙焼している。ここでは $750^{\circ} \mathrm{C}, 900^{\circ} \mathrm{C}, 950$ ${ }^{\circ} \mathrm{C}$ で焙焼した鉱石を $880^{\circ} \mathrm{C}$, coke/ore $=0.1, \mathrm{Cl}_{2}$ 流量 $=$ $3 l / \mathrm{min}$ の条件で塩素化し, 鉄とチタンの選択性の差を調 べた。この結果を Fig. 14 に示したが, 焙焼温度が高いほ ど選択性がよいことがわかつた。これは焙焼温度により生 成する相がちがうためだと考えられる。各焙焼温度での生 成相を次に示した。

$\begin{array}{ll}7500^{\circ} \mathrm{C} & \mathrm{Fe}_{2} \mathrm{O}_{3}, \mathrm{TiO}_{2}, \mathrm{Fe}_{2} \mathrm{TiO}_{5} \\ 900^{\circ} \mathrm{C} & \mathrm{Fe}_{2} \mathrm{O}_{3}, \mathrm{TiO}_{2}, \mathrm{Fe}_{2} \mathrm{TiO}_{5} \\ 950^{\circ} \mathrm{C} & \mathrm{TiO}_{2}, \mathrm{Fe}_{2} \mathrm{TiO}_{5}\end{array}$

これによれば温度が高くなるとへマタイトがルチルと反 応してシュードブルーカイトに移向して, ルチルが減少し ている。熱力学的には塩素との反応性はルチルの方がシュ ードブルーカイト中の $\mathrm{Ti}$ よりよく, $\mathrm{Fe}_{2} \mathrm{O}_{3}$ はシュードブル

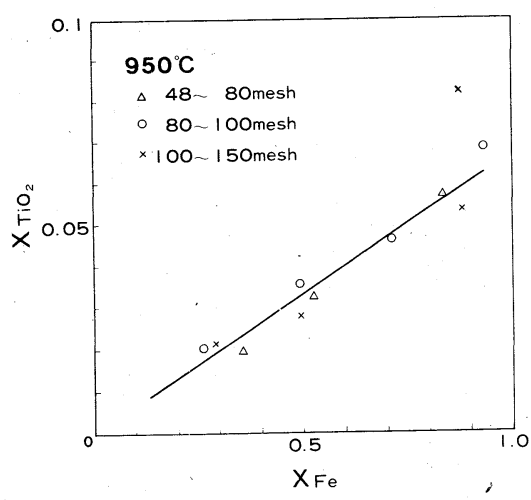

Fig. 12

Effect of particle diameter of ore (horizontal furnace) on the partial chlorination.

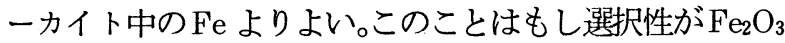
の反応性の差によるものであれば焙焼温度が高いほど反応 性のよい $\mathrm{Fe}_{2} \mathrm{O}_{3}$ が減少するため選択性は悪くなるはずであ る。逆にルチルが選択性に寄与しているとすればFig. 14 の結果と矛盾なく説明できる。

\section{$3 \cdot 3$ 不純物の挙動}

イルメナイト中の主な不純物としては $\mathrm{MnO}, \mathrm{Al}_{2} \mathrm{O}_{3}$ ， $\mathrm{SiO}_{2}, \mathrm{MgO}, \mathrm{CaO}$ などがあるが, これらの塩素化速度を 脱鉄速度の関数として表わした。Fig.15 はそれぞれの不 純物の反応割合を鉄の反応割合 $\left(X_{\mathrm{Fe}}\right)$ で表わしたが, 塩素 化速度は $\mathrm{SiO}_{2}, \mathrm{Al}_{2} \mathrm{O}_{3}, \mathrm{MgO}, \mathrm{CaO}, \mathrm{MnO}$ の順に速くな つた。

これから $\mathrm{Al}_{2} \mathrm{O}_{3}, \mathrm{CaO}$ 以外は温度依存性はほとんどなく, $\mathrm{Al}_{2} \mathrm{O}_{3}, \mathrm{CaO}$ は温度が高くなると塩素化率が高くなる。ま た $880^{\circ} \mathrm{C}$, coke/ore $=0.05 \sim 0.15$ の範井で還元雲用気 の強さをかえて実験したが，これを Fig.16に示した。 $\mathrm{SiO}_{2}$ はほとんど反応せず, $\mathrm{MnO}, \mathrm{MgO}$ については還元雲囲気 による影響はみられなかつた。一方 $\mathrm{Al}_{2} \mathrm{O}_{3}$ は coke/ore= 0.05，0.1ではほとんど差はなかつたが， 0.15 になると 差が顕著に表われた。しかし $\mathrm{CaO}$ はバラツキが大きく定量 的な関係は得られなかつた。なおイルメナイト中にはその 他の不純物として $\mathrm{Nb}_{2} \mathrm{O}_{5}, \mathrm{ZrO}_{2}, \mathrm{P}_{2} \mathrm{O}_{5}, \mathrm{~V}_{2} \mathrm{O}_{5}, \mathrm{Cr}_{2} \mathrm{O}_{3}$ な どがあるが, $X_{\mathrm{Fe}}=0.96$ 付近まで塩素化したとき $\mathrm{Nb}_{2} \mathrm{O}_{5}$ は最初の量の $30 \%, \mathrm{ZrO}_{2}$ は $13 \%, \mathrm{P}_{2} \mathrm{O}_{5}$ は $26 \%, \mathrm{~V}_{2} \mathrm{O}_{5}$ は

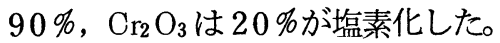

\section{$3 \cdot 4$ 各種イルメナイトの塩素化}

オーストラリア産以外のイルメナイトについても同様に 塩素化実験をおこなつた。鉱石として，アフリカ産（ S.

Africa), ソ連産 ( Irsha, S amotkansky, Kusha), 才 ーストラリア西海岸 (Cable ), アメリカ産 ( Tennessee,
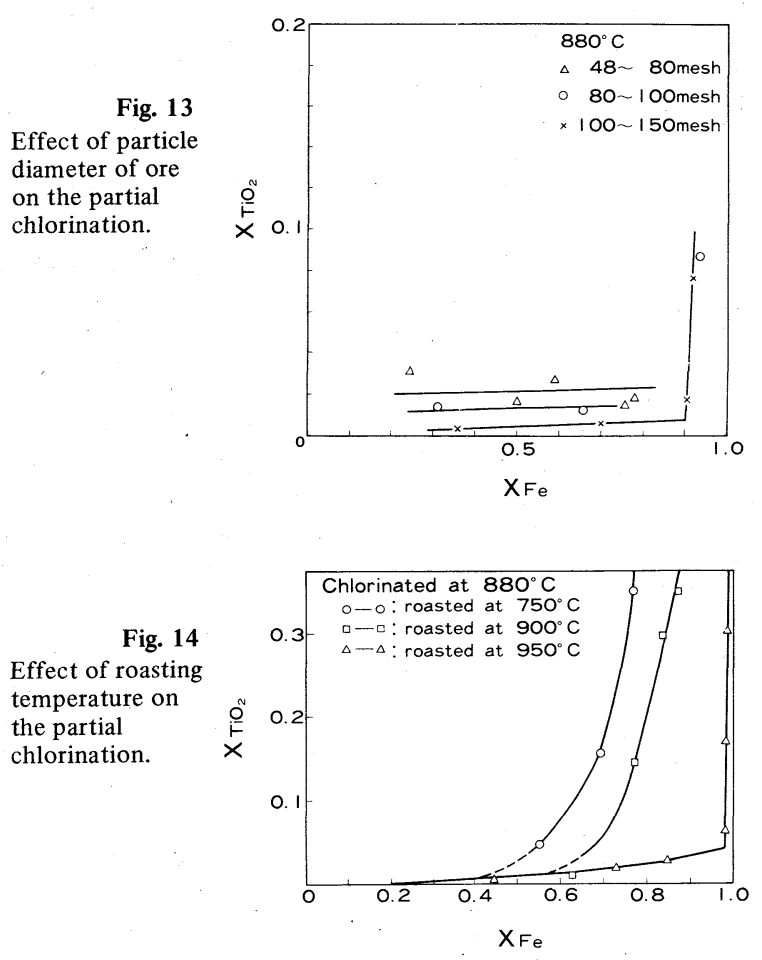

日本鉱業会誌/95 1101（'79-11） $825<45>$ 


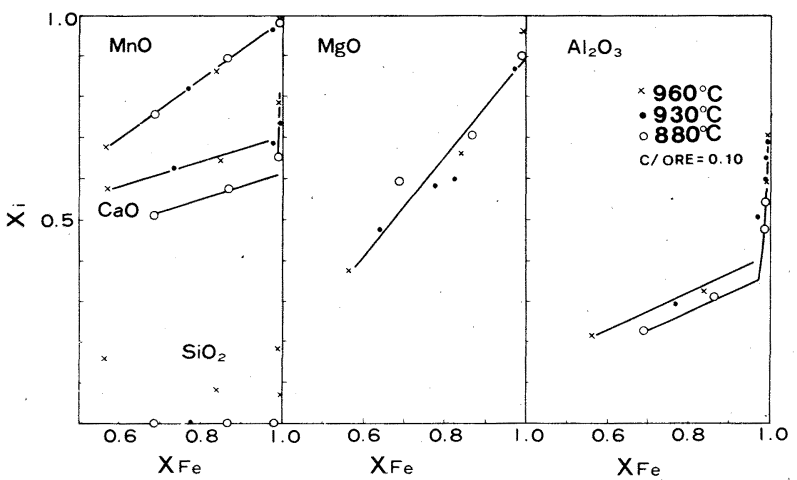

Fig. 15 Extent of reaction of various impurities as a function of the reaction temperature.

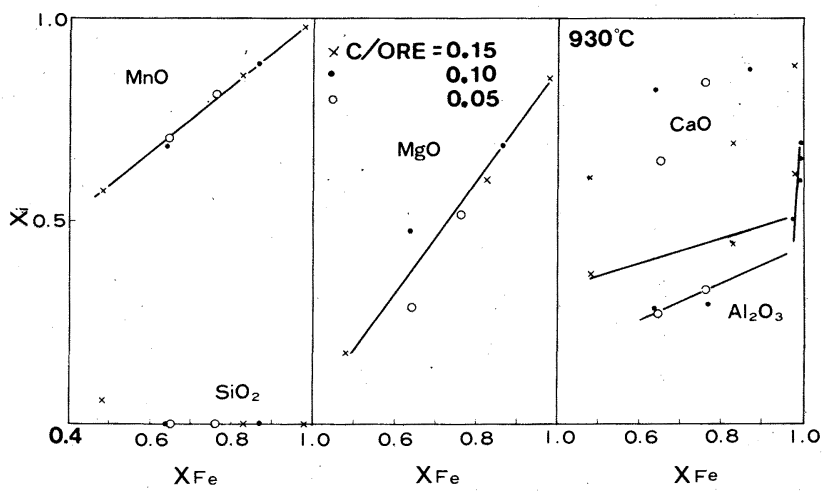

Fig. 16 Extent of reaction of various impurities as a function of coke/ore ratio.

Table 5 Analyses of ores.

\begin{tabular}{|c|c|c|c|c|c|c|c|c|}
\hline & S. Africa & Irsha & Samotkansky & Kusha & Cable & Tennessee & Malaysia & Florida \\
\hline $\mathrm{TiO}_{2}$ & 50.27 & 58.47 & 63.85 & 41.65 & 54.96 & 65.65 & 53.10 & 65.40 \\
\hline $\mathrm{FeO}$ & 36.68 & 6.20 & 0.09 & 35.93 & 19.70 & 0.75 & 27.90 & 2.66 \\
\hline $\mathrm{Fe}_{2} \mathrm{O}_{3}$ & 10.39 & $\cdot 29.14$ & 26.42 & 8.55 & 20.49 & 25.34 & 10.60 & 27.68 \\
\hline $\mathrm{MnO}$ & 0.58 & 0.45 & 0.98 & 0.53 & 1.27 & 0.65 & 3.74 & 1.25 \\
\hline $\mathrm{SiO}_{2}$ & 0.61 & 2.58 & 1.34 & 3.68 & 1.32 & 1.33 & 2.40 & 0.38 \\
\hline $\mathrm{Al}_{2} \mathrm{O}_{3}$ & 0.40 & 0.83 & 1.90 & 2.43 & 1.43 & 1.59 & 1.28 & 1.01 \\
\hline $\mathrm{Cr}_{2} \mathrm{O}_{3}$ & 0.06 & 0.01 & 1.33 & 0.09 & 0.03 & 0.07 & 0.04 & 0.11 \\
\hline $\mathrm{V}_{2} \mathrm{O}_{5}$ & 0.27 & 0.22 & 0.20 & 0.29 & 0.09 & 0.23 & 0.04 & 0.07 \\
\hline $\mathrm{MgO}$ & 0.53 & 0.37 & 0.40 & 1.82 & 0.25 & 0.28 & - & 0.21 \\
\hline $\mathrm{CaO}$ & - & - & - & 0.81 & - & 0.03 & - & 0.13 \\
\hline
\end{tabular}

Fraction; wt $\%$

Table 6 Size distribution of ores.

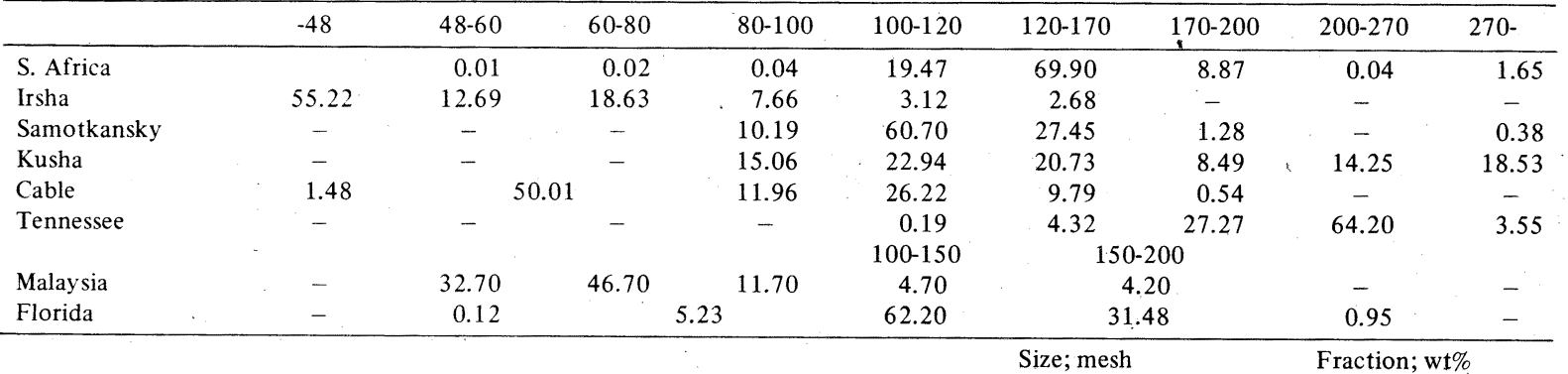

Florida)，Mal ays ia 産のものを使用した。これらの鉱 石の組成および粒度分布はTable 5，6に示した。鉱石の $\mathrm{TiO}_{2}$ は 41〜66\%で，S. Africa, Kushaは鉄分が多く, Samotkansky, TennesseeはFeOが低く, かなり風化が すすんだ鉱石である。また $\mathrm{SiO}_{2}, \mathrm{Al}_{2} \mathrm{O}_{3}$ についてはKusha がもつとも多く, S. Africaがもつとも少ない。Table 6 から計算した鉣石の平均粒径はS. Africa, $0.098 \mathrm{~mm}$, Ir sha, $0.192 \mathrm{~mm}$, Samotkansky, $0.119 \mathrm{~mm}$, Kusha, $0.067 \mathrm{~mm}$, Cable, $0.173 \mathrm{~mm}$, Tennessee, 0.068 $\mathrm{mm}$, Malaysia, $0.202 \mathrm{~mm}$, Florida, $0.123 \mathrm{~mm}$ で, Tennessee, S. Africa が細かく, Malaysiaが一番粗 い。

これらの鉱石を $900^{\circ} \mathrm{C}$, coke/ore $=0.15 て ゙$ 塩素化した ときの結果を Fig.17に示した。ただし Flor ida 産につい ては $880^{\circ} \mathrm{C}, \mathrm{coke} / \mathrm{ore}=0.075$ の条件で塩素化した。 の結果を $1-\left(1-X_{\mathrm{Fe}}\right)^{1 / 3}$ と $t$ の関係で整理すると Fig. 18 を得た。これから $1-\left(1-X_{\mathrm{Fe}}\right)^{1 / 3}$ と $t$ は直線になり各鉱石
について(1)式が成り立ち塩素化速度は unreacted shrinking core model で説明できることがわかつた。なお 時間がたつと直線からずれるのはオーストラリア産イルメ ナイトと同じく, 残留鉄に対するコークス量が相対的にふ えるためである。

\section{4. 結 論}

イルメナイトの塩素化速度, 鉄とチタンの選択性, 不純 物の挙動, 他の種類の鉱石の塩素化について調べ, 次の結 論を得た。

(1) イルメナイトの塩素化速度は鉱石の粒度, コークス の粒度が少ないほど速く, 鉄とチタンの選択性は焙焼温度 が高く, 反応温度が低いほどよかつた。さらにコークス添 加率が小さいほど，また鉱石の粒度が細かいほど選択性は よかつた。

(2) イルメナイトの塩素化では $\mathrm{TiO}_{2}$ の塩素化による 


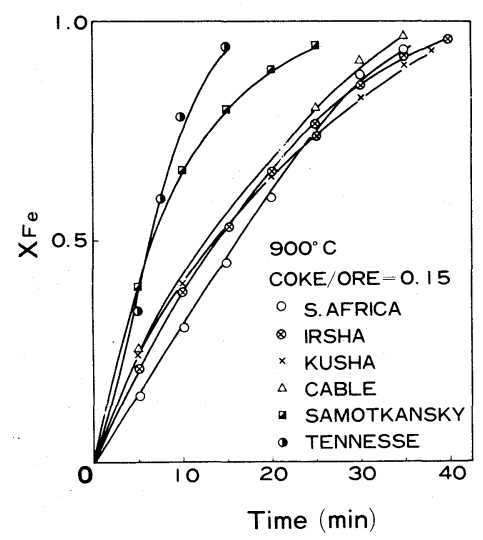

Fig. 17

Extent of reaction at various ilmenite ores as a function of time.

ロスをおさえるため, $X_{\mathrm{Fe}}=0.9$ 付近で反応をコントロー ルしている。このとき $880^{\circ} \mathrm{C}$ で不純物のうち $\mathrm{SiO}_{2}$ はほと んど塩素化せず, $\mathrm{Al}_{2} \mathrm{O}_{3}$ は最初の含有量の $30 \%, \mathrm{MgO}$ は $78 \%, \mathrm{CaO}$ は $58 \%, \mathrm{MnO} 90 \%$ が反応した。

(3) オーストラリア産以外のイルメナイト鉱石の塩素化 反応機構も unreacted shrinking core modelの化学反 応律速で説明できた。

終りに本研究の遂行と発表に援助を賜わつた会社幹部の 方々および実験に多大の協力をいただいた関口桂一氏に深 く感謝申し上げる。

\section{参考文 献}

1) Daubenspeck, J.M. and C. L. Schmidt : U. S. Pat. 2852362, Sept. 16, (1958)

2) Dor ai swamg, L. K., H. C. Bi j awat and M. V. Kunte : Chem. Eng. Progr. 55 (10) 80 88, (1959)

3) Holmes, W. T., II, and L. H. Banning : Bur. Min. Rep. No.6, 497, 23, (1964)

4) Huges, W. and Kenneth, A : Brit. Pat. 992317, May 19, ( 1965 )

5) Ketteridge, I. B., and R. E. Wilmshurst : Australian J. Appl ied. Sci . 15, 90 105, (1964)

6) Love, F. E., anR. Lyons, and J. C. Priscui: U. S. Pat. 2933373, Apr.19, (1960)

7) Madigan, D. C., A. W. Nordin, I. B. Ket teridge, and R. E. Wilmshurst : Australian Pat. 242474, Jan.9,

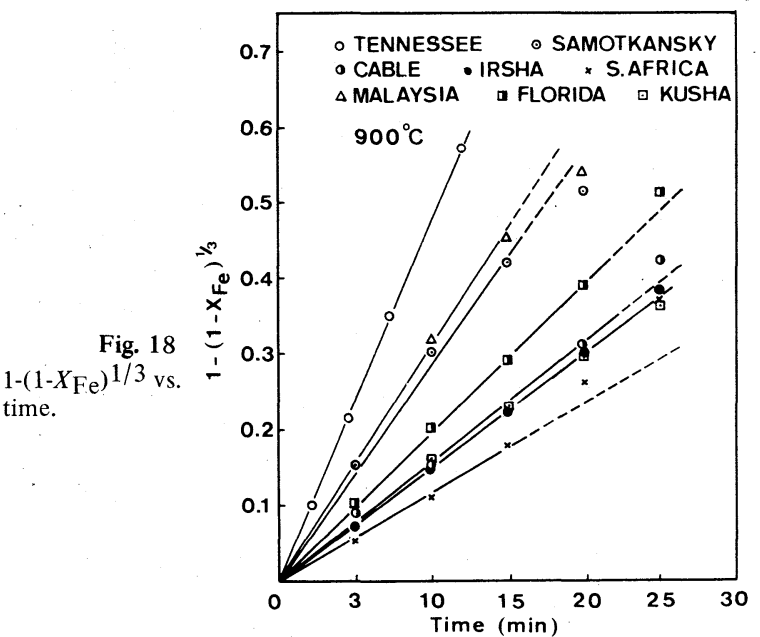

(1963)

8) Rabie, A. A., M. Y. Saada, and S. Y. Ezz : Advances in Extractive Metallurgy. Institution of Mining and Metal lurgy, London, 501 515, (1968)

9) Harris, H. M., A. W. Henderson and T. T. Campbell: TMS - Paper A73 20 Feb., 1 18, (1973)

10) Fukushima, S. and Sugawara, Y : Light Metals, 443 466, (1974)

11) Fuwa, A., E. Kimura and S. Fukushima : 1977 年A IME Annual Meetingで発表, Metallugical Transactions B. Vol. 9 B. Dec., 643 651, (1978)

12) Fuwa, A.,E. Kimura and S. Fukushima : 1977 年A I ME Annual Meetingで発表, 投稿中

13) Kimura, E. and S. Fukushima：1976年 AIME-MMIJ Joint Meetingで発表, 日本鉱業会誌 Vol.95, No.1092 $(1979)$, p. $75 \sim 82$

14) Kimura, E.and S. Fukushima：日本金属学会誌, 43[1], $223 \sim 229,(1979)$

15) Levenspiel, O.: Chemcal Reaction Engineering, 357 377, (1972), John Wiley \& Sons (New York)

16）八木節男・奥平成教：チタンジルュニウム，114～12，（1963）

17) Bergholm, A : Trans. Met. Soc. of AIME 2211121 , (1961)

18) Tittle, K.: Trans. Instn. Min. Metall. Section C, 83, $203,(1974)$

\section{Effects of Variables on Partial Chlorination of Ilmenite}

\section{by Etsuji KIMURA ${ }^{1}$, Akio FUWA ${ }^{2}$ and Seitaro FUKUSHIMA ${ }^{3}$}

Australian ilmenite was chlorinated in a fluidized bed to study the rate of reaction, selective chlorination between $\mathrm{Fe}$ and $\mathrm{TiO}_{2}$ and behavior of the main impurities.

The rate of chlorination was dependent on temperature, particle diameter of ore and coke and chlorine partial pressure. The reaction mechanism was explained by an unreacted shrinking core model, which is based on the assumption that after the reaction proceeds to a certain extent, the solid particle consists of an unreacted core, surrounded by a reacted shell.

Calcined petroleum coke (coarse or fine), unreacted petroleum coke, coal coke, charcoal, anthracite and graphite were compared as reducing agents. Calcined petroleum coke (fine) was found to be most desirable for the impurities - ash and volatile elements - and reactivity. The selective chlorination was dependent on roasting temperature, reaction temperature, particle diameter of ore and coke to ore ratio. The selectivity was improved by higher roasting temperatures, lower reaction temperatures, lower coke to ore ratio and smaller particle diameter.

The major impurities contained in ilmenite were $\mathrm{SiO}_{2}, \mathrm{Al}_{2} \mathrm{O}_{3}, \mathrm{CaO}, \mathrm{MgO}$ and $\mathrm{MnO}$. When the ilmenite ore was chlorinated to $\mathrm{XFe}_{\mathrm{Fe}}=0.9$ at $880^{\circ} \mathrm{C}, \mathrm{SiO}_{2}$ was virtually unreacted and the fractions of reaction for other impurities were respectively; $\mathrm{Al}_{2} \mathrm{O}_{3} 30 \%, \mathrm{MgO} 78 \%, \mathrm{CaO} 58 \%$ and $\mathrm{MnO} 90 \%$. Ilmenite ores from different supply sources - USSR (Irsha, Samotkansky, Kusha), S. Africa, U.S.A. (Florida, Tennessee), Australian west coast (Cable) and Malaysia were also tested. It was found that the unreacted shrinking core model was also applicable to the chlorination of these ores.

(1. Research Engineer, Mitsubishi Metal Research Institute.

3. Professor, Muroran Institute of Technology.
2. New York Representative, Mitsubishi Metal Corp.) 